Trabajos y Comunicaciones, 2da. Época, № 48, e061, julio-diciembre 2018. ISSN 2346-8971

Universidad Nacional de La Plata.

Facultad de Humanidades y Ciencias de la Educación.

Departamento de Historia

\title{
Imágenes personales, corporalidades femeninas y repertorios visuales. Una mujer con cámara de fotos en 1930
}

\author{
Andrea Torricella * \\ * Universidad Nacional de Mar del Plata - CONICET, Argentina \\ andreatorricella@gmail.com
}

Cita sugerida: Torricella, L. (2018). Imágenes personales, corporalidades femeninas y repertorios visuales. Una mujer con cámara de fotos en 1930. Trabajos y Comunicaciones (48), e061. https://doi.org/10.24215/23468971e061

Recibido: 29 de diciembre de 2017 I Aceptado: 20 de abril de 2018 I Publicado: 27 de julio de 2018

Esta obra está bajo licencia Creative Commons Atribución-NoComercial-CompartirIgual 4.0 Internacional

http://creativecommons.org/licenses/by-nc-sa/4.0/deed.es AR 


\section{Imágenes personales, corporalidades femeninas y repertorios visuales. Una mujer con cámara de fotos en 1930}

Self images, feminine corporealities and visual repertories. A woman with a photograph camera in 1930

Andrea Torricella

Universidad Nacional de Mar del Plata - CONICET, Argentina

andreatorricella@gmail.com

\section{RESUMEN:}

Este artículo se basa en una metodología que hacer dialogar representaciones de fotografías con otros repertorios visuales de la misma época. Como conclusiones sostenemos que las representaciones de género construidas en las fotos no son reflejos del estereotipo dominante de mujer, si no que combinan diversos repertorios, generando como resultado ciertos desplazamientos en las normatividades. Se analiza un corpus de fotografías pertenecientes a una mujer que poseía una cámara de fotos y tomaba imágenes de su estadía en las sierras de Córdoba, argentina en la década de 1930. El objetivo es estudiar un caso significativo que pone al descubierto el modo en que las representaciones visuales del cuerpo femenino fueron una de las vías por las cuales se construyeron las identidades de género.

Palabras Clave: Visualidad; Género; Cuerpo; Fotografía; Salud; Belleza.

\section{Abstract:}

This article is based on a methodology that links representations of photographs with other visual repertoires of the same period. As conclusions we argue that the gender representations constructed in the photos are not reflections of the dominant stereotype of gender, but rather that they combine diverse repertoires, generating as a result certain displacements in the normativities. A corpus of photographs belonging to a woman who owned a camera and took pictures of her stay in the mountains of Córdoba, Argentina in the 1930s, is analyzed. The objective is to study a significant case that reveals the way in which visual representations of the female body were one of the ways in which gender identities were constructed.

KEYWORDS: Visuality; Gender; Body; Photography; Health; Beauty. 


\section{IMAGEN 1}

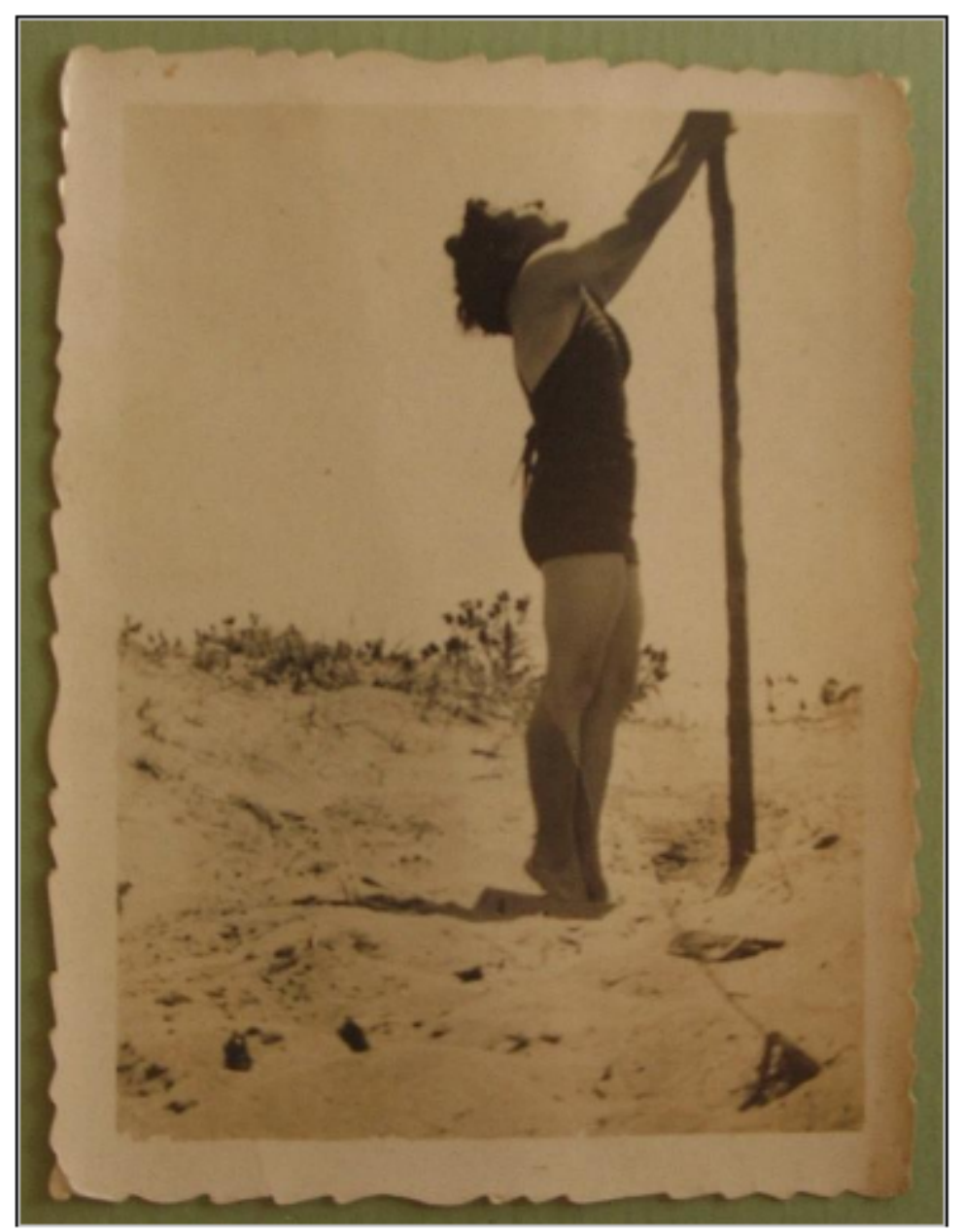

Esther, circa 1936

Mediados de la década de 1930. Una silueta femenina en una playa, con traje de baño. Aparentemente está sola y posando para la cámara, la toma simula cierto desenfado. ¿Quién habría tomado la fotografía? La mujer retratada ¿quien sería? ¿qué estaría haciendo? Al verla, me venían a la mente los clásicos libros que afirmaban que el cuerpo desnudo de la mujer era objetivado al ser retratado por la cámara, que esta última representaba la mirada masculina y que reproducía el control social sobre las mujeres en general. ${ }^{1}$ ¿Qué habría significado esta pequeña imagen para la mujer allí retratada, si es que era ella quien la conservaba o la recordaba?

Esta fotografía, y muchas similares que analizo en este artículo, forman parte de un acervo de imágenes que me ofreció Irene, una entrevistada, durante el trabajo de campo de mi investigación de doctorado en el año 2009. Quién está retratada ahí es Esther, su madre. Esther había nacido en 1911, en Lobería, hija de un matrimonio que tuvo 10 hijos ( 5 mujeres y 5 varones), del cual ella fue la anteúltima. Su padre era arrendatario de campos y según nos contaba su hija, éste tenía mucho dinero ya que había podido comprar un auto de ocho asientos. ${ }^{2}$ En las vacaciones de verano, aproximadamente alrededor de sus 25 años, Esther se iba a Córdoba, a La Falda, a casa de unos primos. Viajaba sola y por razones de salud. Tenía un problema en las cuerdas vocales y el clima serrano era considerado beneficioso para su afección. Su hija me contó cuál había sido la razón de su deterioro:

\footnotetext{
"Mi mamá cuando era chica se cayó a un pozo, un pozo que había en el campo con barro. Los hermanos la sacaron y había tragado barro, entonces se lastimó una cuerda vocal. Y mi mamá siempre fue afónica, pero muy muy afónica. Entonces, cuando fue grande, iba allá a Córdoba porque decían que el aire de Córdoba era bueno...." 3
} 
Esther trabajaba en el campo con sus padres y estudiaba bordado a máquina, oficio que años más tarde se dedicaría a enseñar. Se casó recién en 1941, a los 30 años, con Fernando, dos años más joven que ella y amigo de su hermano menor. Se conocieron en su casa, cuando Fernando fue a reparar los colchones de lana de toda la familia, y según su hija, el noviazgo fue muy corto, porque era la única que todavía no se había casado: "Para todos era la tía solterona", repetía Irene en la entrevista. Tan difícil fue de sobrellevar para Esther esa diferencia de edad y su madurez al casarse, que le dijo a sus hijas y a los vecinos que ella era dos años menor que su marido. Con Fernando tuvo 3 hijos, dos mujeres (a los 32 y 33 años) y un varón (a los 42 años).

Esther falleció en 2007. Las fotografías que su hija me dio y le habían pertenecido estaban conservadas en dos valijas pequeñas. Todas ellas (incluidos dos álbumes) eran consideradas como "fotos de Esther". Cuando le pregunté a su hija en la entrevista si podría periodizar la época a la cual refieren las imágenes, por ejemplo si se correspondían a la época de cuando ellos eran chicos, las definió como "de mamá... todas de mamá, de la juventud".

Cuando observaba estas imágenes, notaba que no son las típicas fotos de familia que se describe en la literatura clásica sobre el tema (Silva, 1998; Moreira Leite, 2003, Bourdieu, 2003). La familia, las vacaciones en familia, el tiempo de la infancia y los rituales familiares estaban en un segundo plano, en pocas fotos, sueltas y desordenadas. En mi proceso de búsqueda de acervos fotográficos personales, este corpus también resaltaba por su singularidad. Todas eran imágenes de una joven y su grupo de amigos/primos y fueron realizadas en contextos de camaradería y tiempo libre. Lo más característico de estas fotografías, además de estas condiciones de producción, es la centralidad que poseen los cuerpos de los retratados, sus poses, la apariencia y la gestualidad. Es un caso muy particular porque una mujer es la dueña de la cámara fotográfica y la protagonista de la serie, quien además tiene una relación lúdica con el aparato. En general, la bibliografía especializada sostiene que eran los hombres quienes se encargaban de la tecnología y el saber hacer fotográfico y las mujeres quienes cuidaban la memoria familiar a través del cuidado de las fotografías resultantes (Silva, 1998). Mi interés en este artículo es analizar a partir del caso particular de una mujer fotógrafa amateur, el modo en que las prácticas fotográficas significaron un cambio en la experiencia de la corporalidad y de la subjetividad y, a la vez, modelaron las corporalidades en clave de género. Considero que es un caso particular que permite que nos hagamos ciertas preguntas en torno a una trayectoria femenina no hegemónica, donde la familia no es el centro de las representaciones, y a unos usos particulares del medio fotográfico, reservado a ciertos sectores sociales y con finalidades diferentes todavía en esa época. Pero a la vez es un caso representativo de un horizonte de posibilidades de la época y de los modos en que los sujetos pueden ejercer cierto margen de libertad condicionada en la configuración de su identidad de género. ${ }^{4}$

Como sostengo en otro lado, las prácticas fotográficas construyeron, entre otros dispositivos, los sentidos sobre ser hombre o ser mujer con un eje relevante en la corporalidad (Torricella, 2012). ${ }^{5}$ Estas representaciones visuales dan cuenta de identidades ancladas en la apariencia corporal en donde las prácticas individuales se nutrieron de los repertorios visuales epocales. Hacia 1930 en Argentina se inicia un proceso de democratización de las prácticas fotográficas domésticas, las cuales comienzan a ser más accesibles a los sectores medios y populares en ascenso. ${ }^{6}$ Pero recién hacia 1960 este proceso tendrá mayor difusión entre clases sociales y a partir de una diversidad de prácticas de representación de la propia imagen (Príamo, 2000). ${ }^{7}$ La fotografía se estableció como un instrumento compartido de auto conocimiento y representación familiar. Estas representaciones se construyeron con cierto grado de participación de los sujetos, quienes las tomaban o accedían a posar para la cámara. Las fotos familiares tuvieron un rol importante en la construcción visual de las identidades de género durante el período 1930-1960. Entre aquellas décadas, el modelo de familia y las identidades heteronormativas de género se transformaron y consolidaron en torno a representaciones y símbolos característicos de los sectores medios (Cosse, 2010, Pérez, 2012). Este cambio tuvo, como su contexto, un proceso de transformación de las normatividades relativas al cuerpo en donde -si a comienzos de siglo primaban las ideas de salud, higiene y raza-,a medida que avanza la centuria estas nociones se conjugaron con estándares democratizados de belleza, salud y bienestar (Aisenstein, 2006). 
En lo que sigue me interesa analizar este proceso a partir del prisma de las fotografías de Esther ¿De qué manera las fotografías de Esther navegan entre los diversos repertorios disponibles en la época que hacían posible la representación de un cuerpo femenino? ¿Cómo interpretar las representaciones fotográficas? El análisis no se centra exclusivamente en aquello que muestran, sino que a partir de una metodología de análisis se reconstruiran representaciones visuales de la época que permiten darle sentido a las fotos de Esther. Siguiendo a Griselda Pollock (1994), considero que la eficacia de las representaciones recae en el intercambio con otras representaciones. ¿Cómo analizar el significado de una imagen? Una opción podría ser estudiar aquello que muestra y problematizar la relación con ese referente que estuvo delante de la cámara. Otra, que en nuestro caso fue complementaria de la anterior, es pensar que las fotografías son constructos culturales que adquieren significado en los contextos en que fueron elaborados. En este sentido, reconstruir repertorios normativos sobre aquello que las imágenes muestran me proveyó de coordenadas interpretativas (Torricella, 2018). Reconstruyo ciertos contextos normativos (sobre los estereotipos de género, las maneras de mostrar un cuerpo y de modelarlo) porque sostengo que fueron dimensiones con las cuales las representaciones elaboradas por Esther pueden haber navegado. Para ello he utilizado fuentes secundarias sobre las transformaciones en la feminidad y la corporalidad entre los años 1930 y 1950 e imágenes de prensa escrita también de la misma época, todas en relación al cuerpo, al ejercicio físico y la salud.

\section{MOSTRAR EL CUERPO SALUDABLE Y BELLO: OTRAS REPRESENTACIONES DE LO FEMENINO}

En muchas de las fotografías de su estadía en La Falda, Esther aparece con sus primos y amigos en traje de baño y botas. Una de las actividades que allí realizaban era ir de paseo algunas veces al Río Grande y darse unos baños. Las fotografías suelen tener detrás una inscripción que las ubica temporal y espacialmente. En la imagen $n^{\circ} 2$, Esther es la primera de la izquierda. Está retratada junto con una prima y una amiga, luciendo sus trajes de baños y dejando ver sus piernas.

\section{IMAGEN 2}

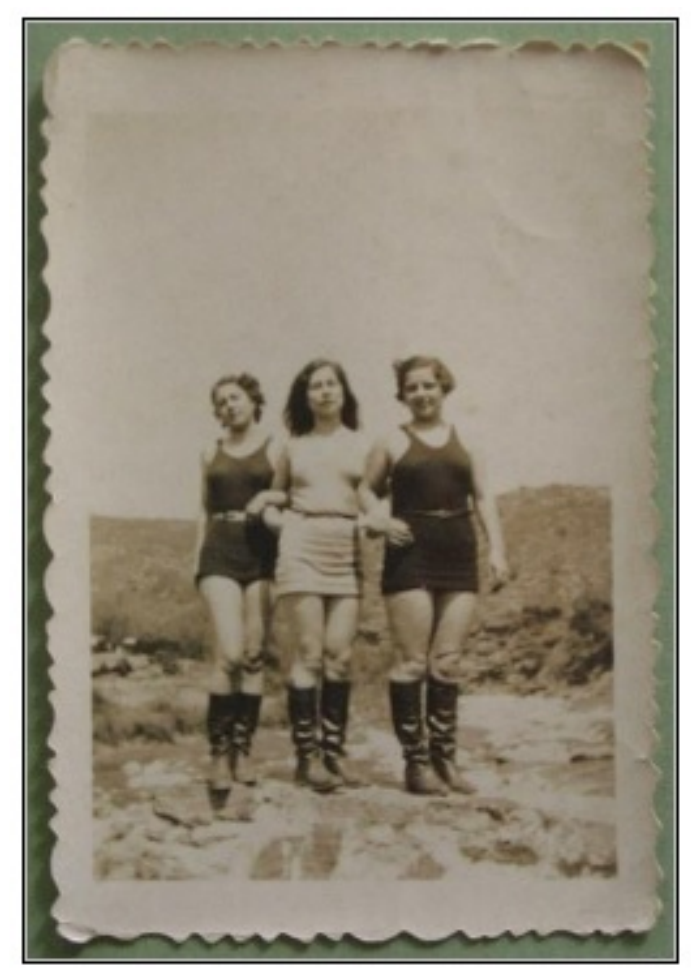




\section{IMAGEN 3}

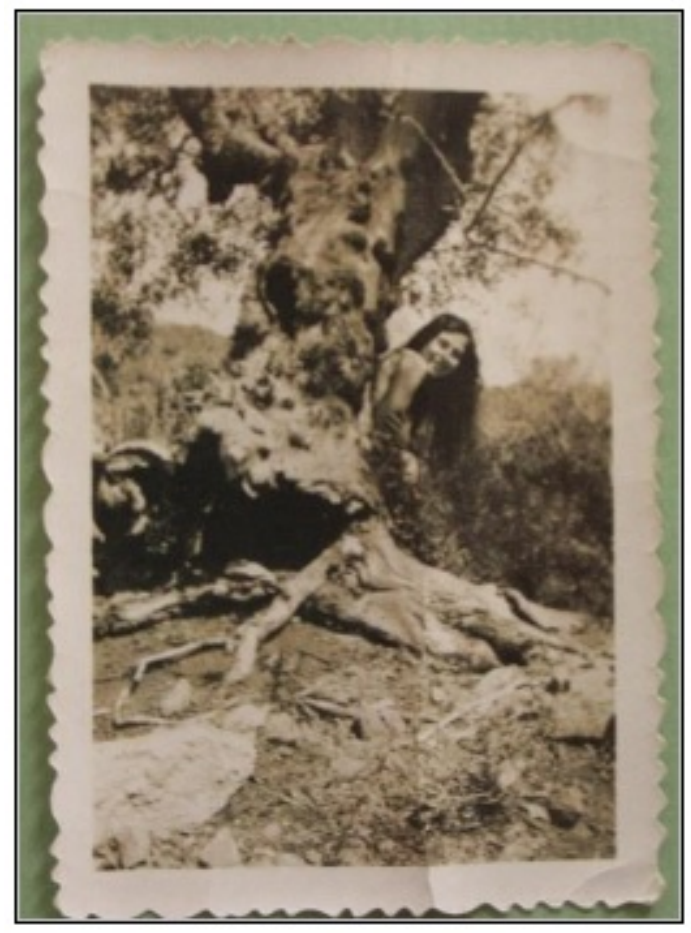

El uso de la cámara de fotos por parte de Esther respondía al juego y la seducción antes que a las clásicas imágenes familiares o de turismo. En primer lugar, los cuerpos son presentados en tanto que cuerpos bellos, sus formas y superficies no eran ocultadas ni tapadas, más que con los trajes de baño y las botas que las protegerían del relieve agreste. Las imágenes dan cuenta de un contexto de intimidad en el que esas fotografías eran escenificadas. La imagen $n^{\circ} 3$ es una fotografía que aparenta sorprender -quizás en el momento del vestido- a una de las muchachas que salía de paseo con ella. Es insinuante que la joven tiene casi todo el cuerpo detrás del árbol, sonriente solo deja ver parte de su espalda, y que no haya signos de su vestimenta más allá de lo que tapa el árbol. Generalmente, en las fotos de Esther, los escenarios en los que se producen las tomas fotográficas parecen ser lugares deshabitados, donde un grupo de jóvenes tenía momentos de recreación y esparcimiento al reparo de la mirada de los otros.

El calificativo de "la tía solterona" con el que su familia la nombró, resulta un tanto inadecuado para definir las imágenes que Esther poseía de ese período. Las fotografías de ese tiempo en La Falda no están recubiertas de un sentido negativo, como el que suele entenderse sobre la soltería (no matrimonio) tanto en el comentario como en las expectativas femeninas para mediados de siglo XX. ${ }^{8}$ Una carta de lectoras de la revista Vosotras, escrita por una vendedora de 35 años en 1950, sintetizaba los prejuicios en torno ser una mujer que no se había casado y tenía una edad avanzada, según las expectativas de esa época: sentía que todo el barrio se burlaba de ella o la miraba con lástima, y se atormentaba pensando que con los años sería una carga para la familia. ${ }^{9} \mathrm{Si}$ bien algunas autoras sostienen que no casarse comienza a ser una representación visible hacia los años $40 \mathrm{y}$ señala ciertas fisuras en el modelo de domesticidad (Queirolo, 2006), en general la soltería no fue una opción socialmente valorada hasta más avanzado el siglo XX (Cosse, 2006).

Muchas de las tomas tienen por motivo el cuerpo bello y esbelto de Esther (imágenes nos 4, 5, 6) quien no aparenta ningún tipo de pudor frente a la cámara, incluso cuando en la sombra se ve una silueta masculina fotografiando (imagen 4). Todo lo contrario, Esther despliega todo su encanto y diversión (casi como una estrella cinematográfica) en varias de las instantáneas. Son fotografías cuidadosamente planificadas, como la imagen 6, en donde los retratados juegan con las poses. El río no representa solo un escenario en donde se realizan las tomas, está incorporado en las representaciones para dar un sentido de osadía y recreación. Las 
fotografías del momento del baño en el río La Falda son abundantes entre las que Esther conserva, tomas en traje de baño, pero también muchas de ellas dentro del agua, dando cuenta de los momentos de diversión y descanso con los de la vida saludable en la naturaleza, al aire libre y en el agua. Como puede verse más abajo en las imágenes 7, 9 y 10 Esther y sus primos se fotografían tomando baños de sol y de agua.

\section{IMAGEN 4}

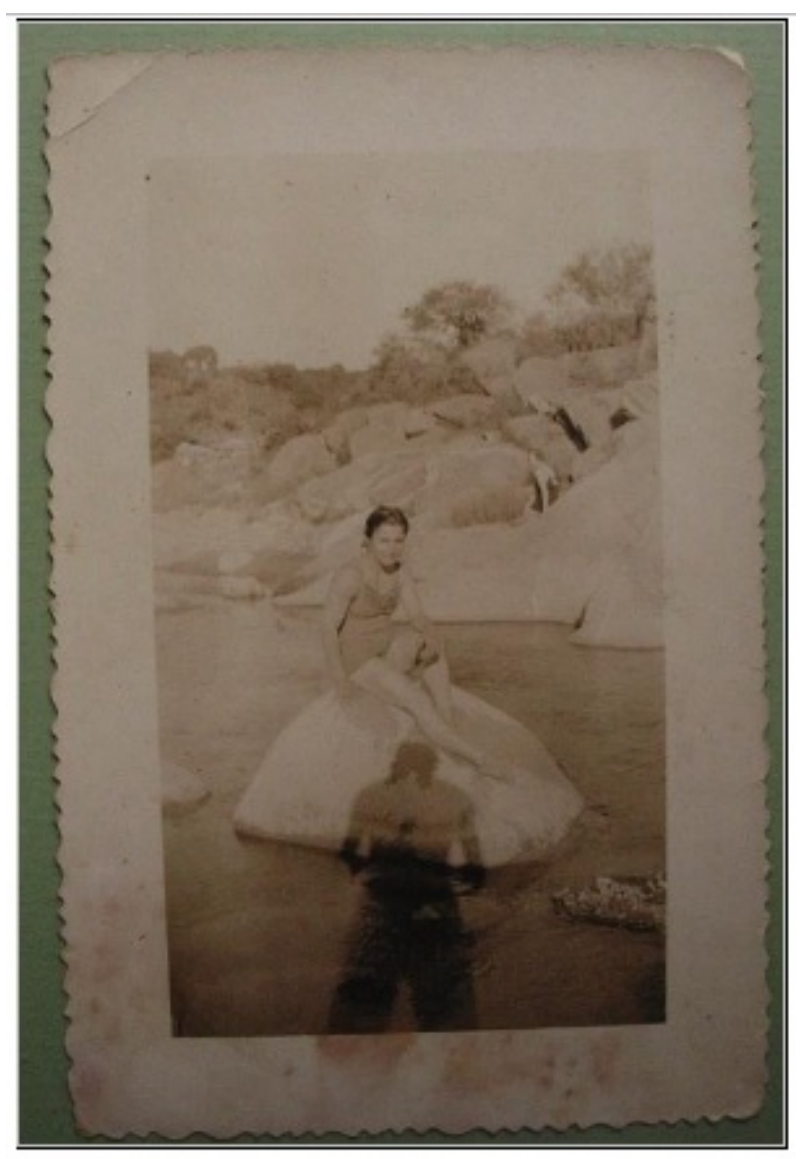

"11/2/36 La Falda - En el Río La Falda” 


\section{IMAGEN 5}

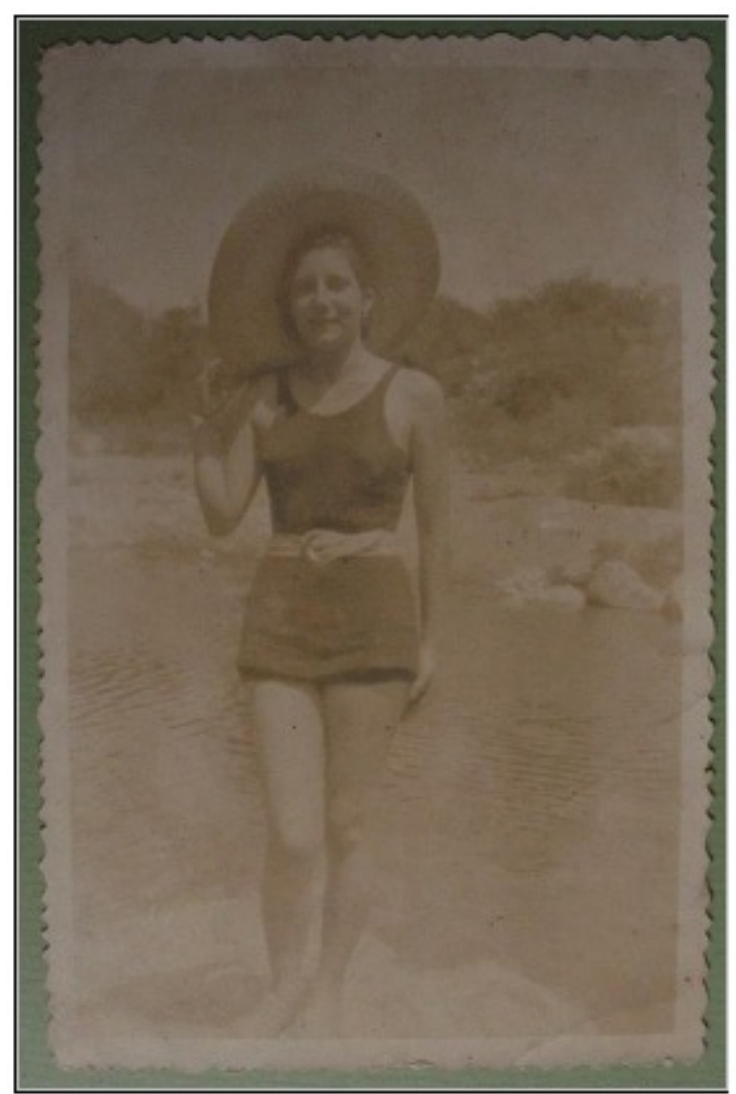

“2/2/936 La Falda - Río Grande”

IMAGEN 6

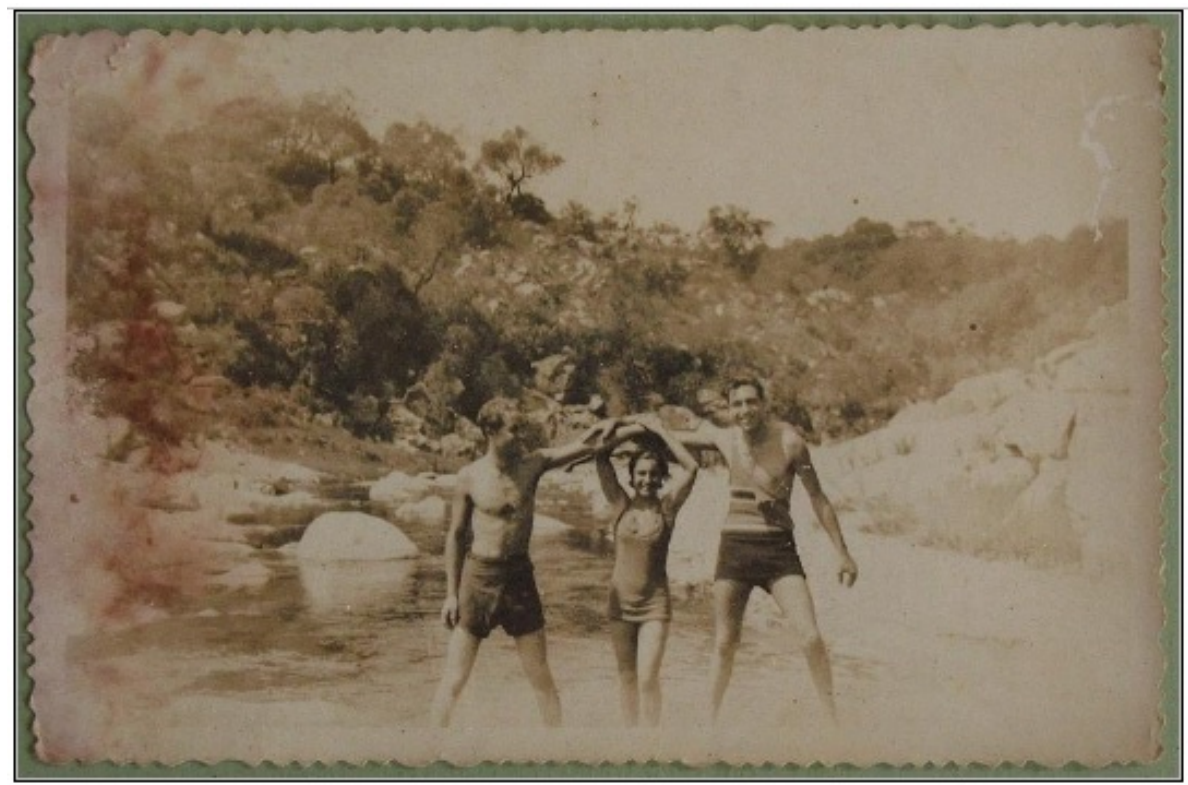

Esther, circa 1936

A principios de siglo XX, bañarse en el agua no era algo común a raíz de la incomodidad que significaban los trajes de baño que cubrían casi todo el cuerpo. Entre 1920 y 1930 se produce un cambio en las pautas de moralidad, vestido y consumo donde se revaloriza el cuerpo de la mujer y en particular las piernas como 
una mercancía visual. Las publicidades harán uso de la sensualidad de la mujer para vender los productos que anunciaban. ${ }^{10}$

Esta valorización del cuerpo de la mujer también está acompañada por la nueva relevancia social que cobra el baño de agua y de sol, el aire libre y el ejercicio físico no solo en términos estéticos, sino de buena salud: el bronceado, como si el sol fabricase energía, vigorizaba los cuerpos. Después de la primera Guerra Mundial, la naturaleza y la desnudez, la fuerza y la musculatura del cuerpo cobran un valor más relevante a la par que el ocio y el tiempo libre se democratizan - el turismo, los paseos por el campo."El músculo pierde su antigua connotación obrera, la piel bronceada se distancia de sus orígenes campesinos. El cuerpo puede tratar de ser 'atlético', esforzarse más, ocupar un tiempo que no se le había dado antes”(Vigarello, 2006: 176).

Numerosos fueron los consejos y recomendaciones sobre las virtudes del agua y el baño. Oscilaban entre los beneficios para la salud física y psíquica, para la higiene y las buenas relaciones sociales a partir del buen olor, para el fortalecimiento de los músculos y la mejora de la salud de los órganos a través de la natación. Pero también se fundamentaban en el grado de modernidad que esas prácticas darían a sus ejecutantes. La revista Cultura Sexual y Física desde fines de 1930 y durante la década de 1940 abundaba en ellos sosteniendo además que "El baño es un signo de liberación moderna"

\section{IMAGEN 7}

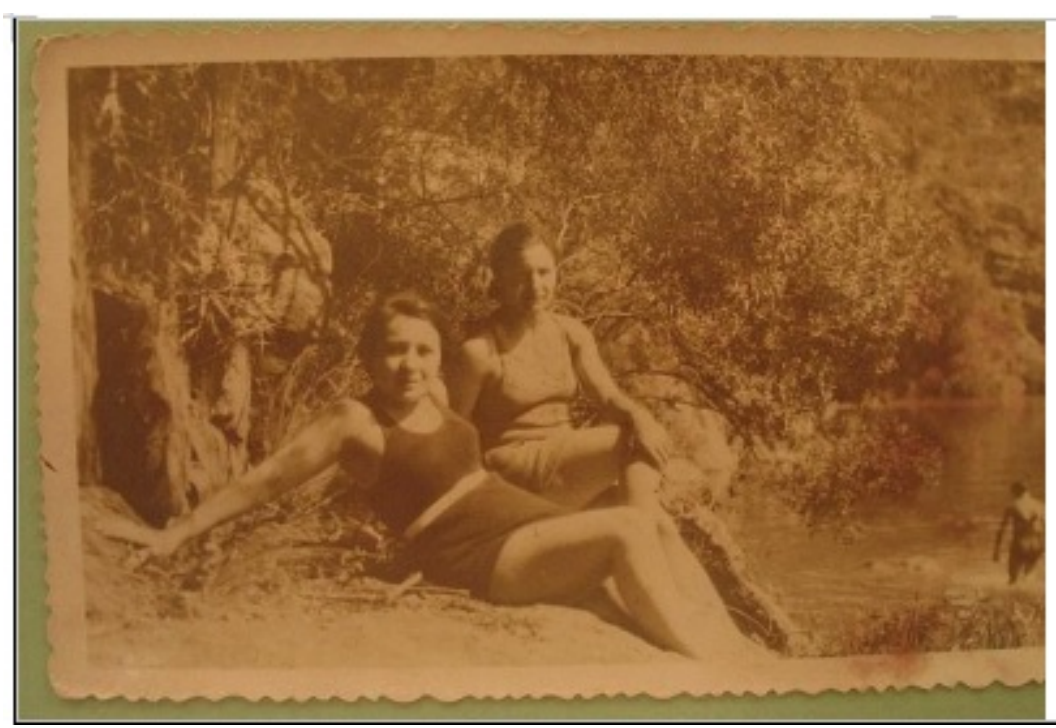

"23/2/936 A la orilla del Dique de las siete caídas"

IMAGEN 8

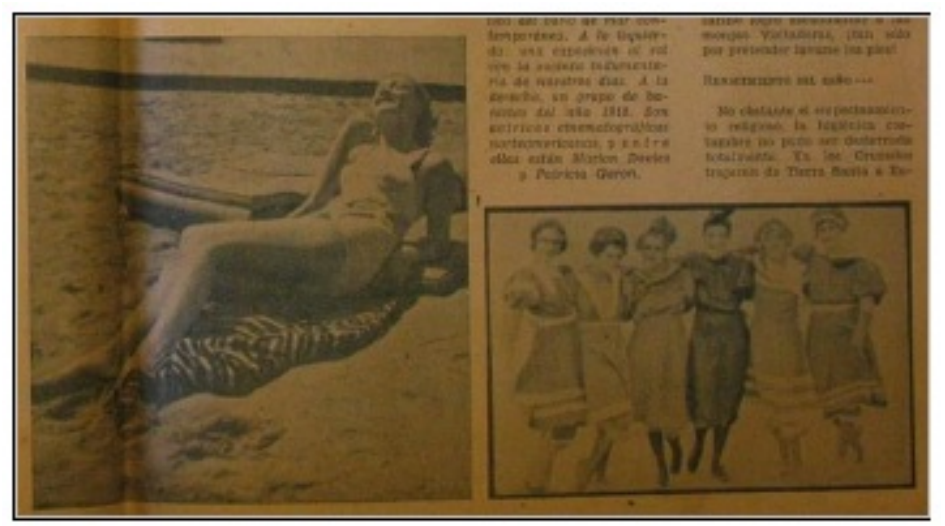

"El baño es un signo de liberación moderna”, Cultura sexual y fisica, Noviembre de 1938 


\section{IMAGEN 9}

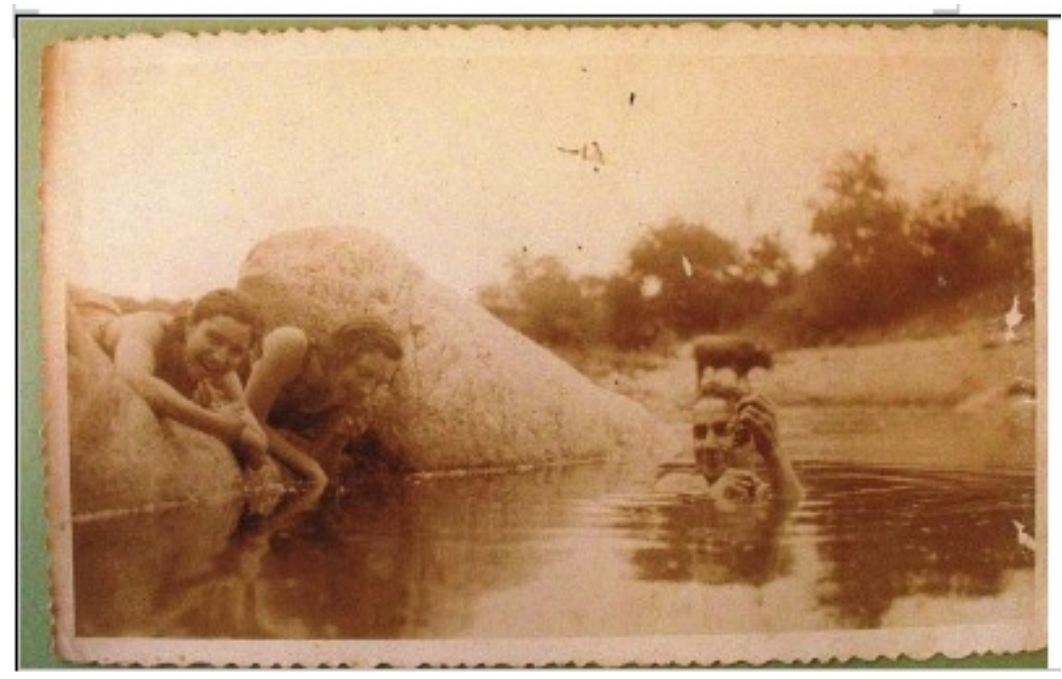

"Febrero de 1936"

\section{IMAGEN 10}

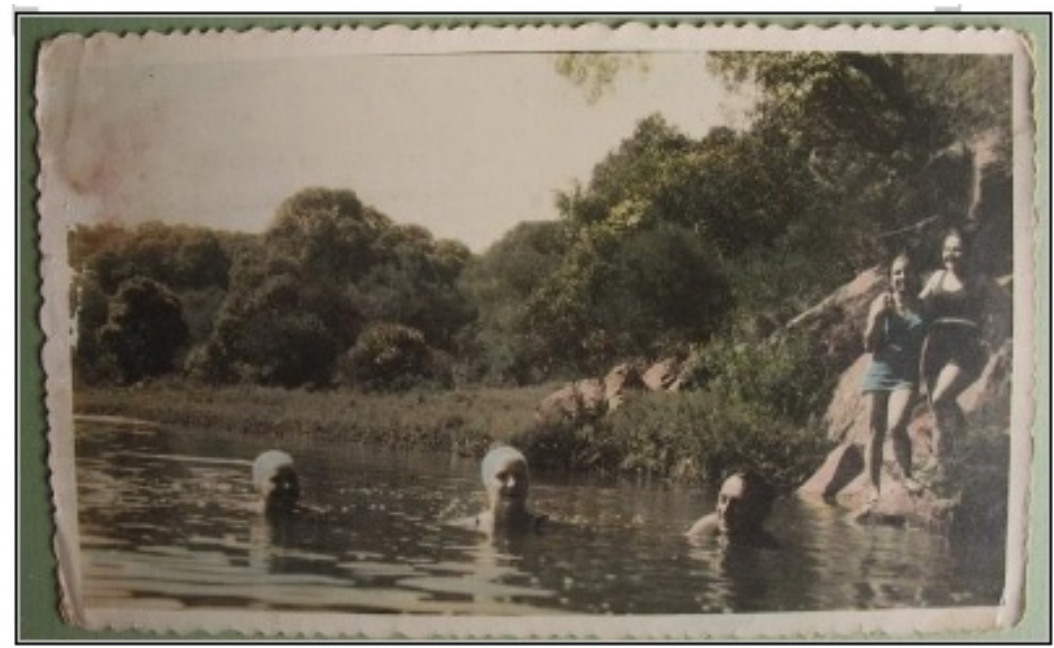

“24/2/36- A mis queridos padres y hermanos con el más sincero cariño, Esther”

"Desde el punto de vista de la cultura sexual y estética no hay duda que ha ganado mucho nuestra generación, que se ha habituado a admirar la belleza de las formas sin experimentar el impulso erótico que tanto se exaltaba antes ante la reticencia y el pudor mojigato de nuestros antepasados. Las playas de hoy son verdaderos torneos de belleza física, semejantes en cierto sentido, a los de la antigua Grecia, que rendía culto a las formas magníficas de hombres y mujeres, suscitando en ambos sexos el saludable impulso de emulación física y estética. Admirable conquista de los tiempos, en la que nuestra juventud encuentra motivo para superar su perfección física y poder exhibirla, sin el temor de nuestras abuelas, a la admiración de los demás”. ${ }^{11}$

Las fotos de Esther son fotos de cuerpos en trajes de baño, en un contexto de cierta intimidad, pero no son fotos "privadas" que ella conservaría con exclusividad. Son fotos para mostrar, que presuponen un destinatario, sus padres a quienes ella se las enviaba según las inscripciones detrás. Además, los condicionamientos del medio tecnológico también añaden particularidades a los significados que esas fotos tenían: debían pasar por los ojos de un tercero, aquel que las revelaba. ${ }^{12}$

Entre las fotografías de Esther conservadas en la valija había dos álbumes, uno del servicio militar de su marido (un álbum institucional) y el otro, suyo (de 55 páginas), en el cual primaban las fotos de La Falda y algunas fotografías de sus sobrinos (imágenes nos 11-12 y 17-23) todas situadas aproximadamente entre $1935-1940$ 


\section{IMAGEN 11}

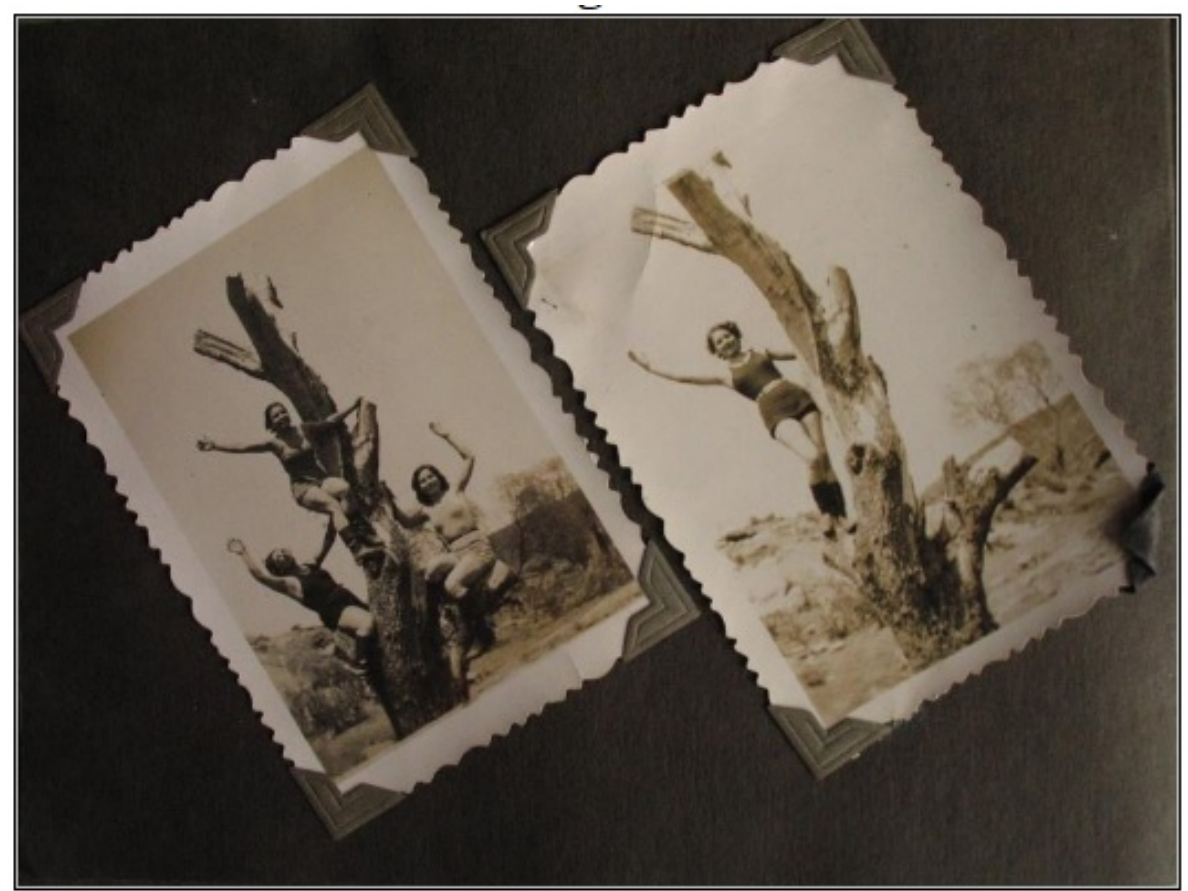

Página 4 del álbum

\section{IMAGEN 12}

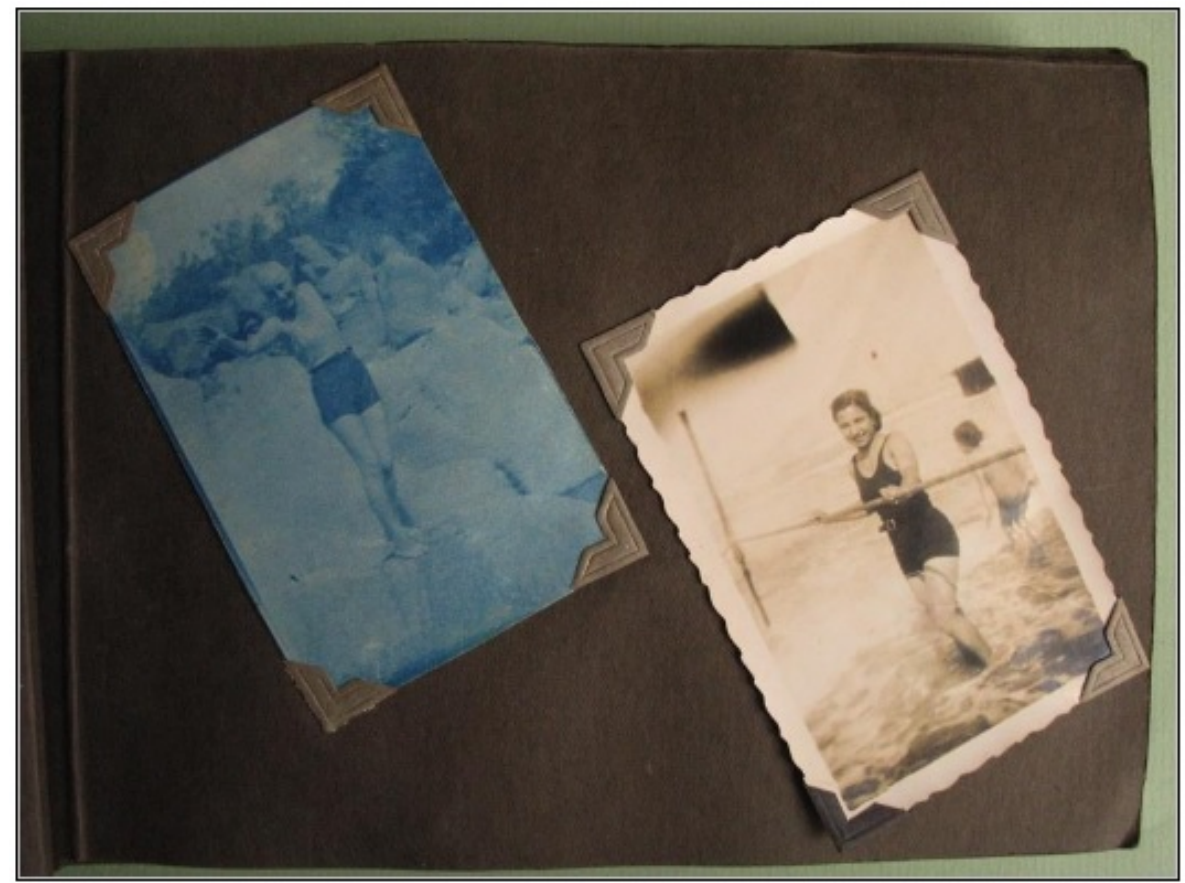

Página 5 del álbum

Vuelven a aparecer fotografías en traje de baño, esta vez con posiciones más atléticas como era posar trepada en los árboles o simulando actitudes deportivas (imágenes nos 11, 12 y 18). Formas de mostrar el cuerpo relacionadas a las conquistas femeninas del período (Barrancos, 2000), pero también, y teniendo en cuenta el problema de salud de Esther, indicadoras de buen estado físico.

Entre 1870 y 1940 el temor a la tuberculosis como una enfermedad que se creía estaba causada por relaciones defectuosas entre la sociedad y el medio ambiente, propició el auge de determinadas prácticas 
asociadas al aire puro y los ambientes naturales (Armus, 2007). Las Sierras de Córdoba ocuparon un lugar simbólico de gran fuerza en las expectativas de cura del tuberculoso o incluso de aquellos que sin serlo pensaban en la temporada cordobesa como un recurso preventivo y reparador:

"Al final de cuentas, la cura de reposo no demandaba ni gran infraestructura ni gran confort. Sí, en cambio, mucha limpieza y alimentación adecuada. Se buscaba combinar la vida al aire libre, el control médico y el descanso con un clima supuestamente apropiado que para algunos debía ofrecer aire frío y seco pero para otros aire caliente y seco o aire húmedo y cálido, o cualquiera de estos y otros factores combinados" (Armus, 2007: 342).

Las piernas de Esther y de las otras muchachas retratadas también son un tópico novedoso en las representaciones femeninas del período. La preocupación por las piernas y la delgadez del cuerpo fue un tema sensible en la época para las mujeres. Ejercicios físicos destinados a las mujeres pueden observarse en muchas de las revistas destinadas a un público femenino. Si bien estos consejos seguían sosteniendo una idea de la especificidad maternal de las mujeres y por eso el cuidado de su salud, también los criterios de belleza entran en cierta coalición con esa homogeneidad en los sentidos de lo femenino. Como sostiene Georges Vigarello, la belleza en el siglo XX se caracteriza por un énfasis en las líneas alargadas, ejemplificadas en la exhibición de las piernas:

"La belleza del siglo XX se inaugura con un cambio de silueta, en una 'metamorfosis' que comienza entre 1910 y 1920, con líneas estiradas y gestos aligerados. Se despliegan las piernas, los peinados se levatan, la altura se impone. Las imágenes de Vogue o de Femina, de 1920, no tienen relación con las de 1900: 'todas las mujeres dan la impresión de haber crecido'. El aspecto se despliega de la imagen de la flor a la del tallo, de la letra $S$ a la letra I. Se trata de una extensión 'desmesurada' en relación con la -ya sensible- de comienzos del siglo XX.

Esa gracilidad no es solamente formal. Pretende revelar la autonomía en las líneas del cuerpo, ilustrando una profunda transformación de la mujer"(Vigarello, 2005: 195).

La siguiente nota (imagen $n^{\circ} 13$ ) tomada de la revista El Gráfico hace referencia no solo a la importancia de la delgadez, sino también a que esos deseos de cuerpos estilizados son compartidos por mujeres trabajadoras, pero en la oficina. A diferencia del trabajo de la mujer obrera, erradicable por los males que causaba en el cuerpo de las mujeres madres y futuras madres (Barrancos, 2007; Lobato, 2005), el trabajo de oficina, un oficio moderno (Queirolo, 2008, 2012), engordaba ciertas partes del cuerpo de la mujeres que debían ser ejercitados. 


\section{IMAGEN 13}

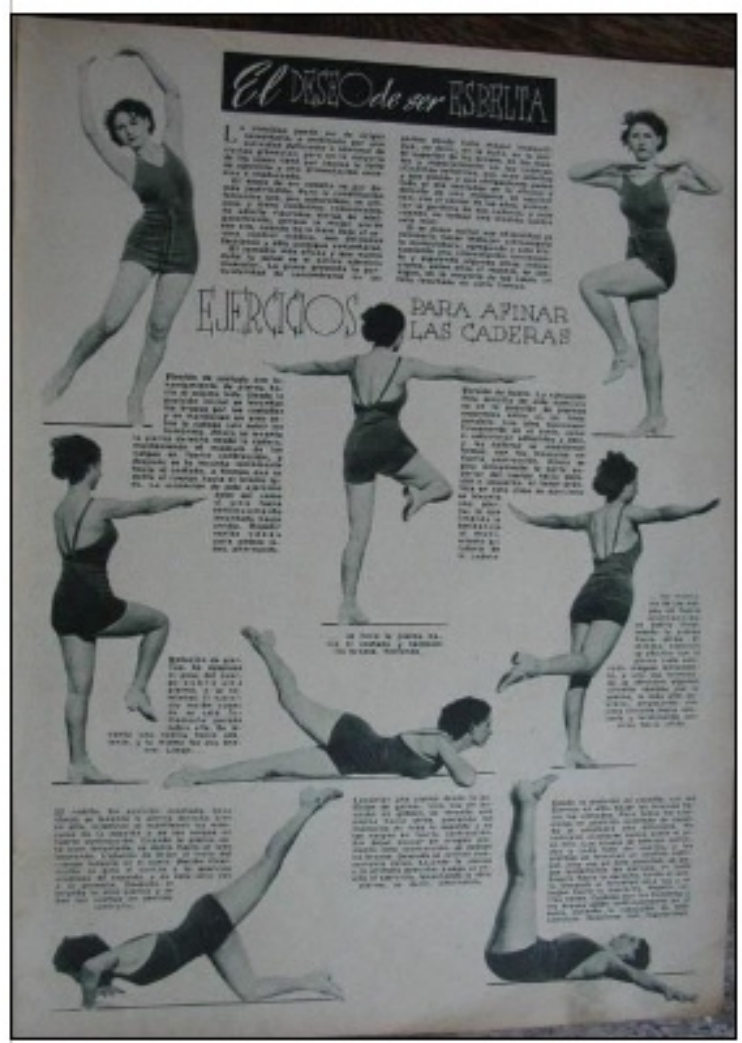

"El deseo de ser esbelta es por demás justificable. Pero la constitución femenina que, por naturaleza, es adiposa y tiene contornos redondeados, no admite rigurosas dietas de adelgazamiento, porque la mujer pierde con ello, cuando no lo hace bajo el severo control médico, sus delicadas facciones y sólo consigue avejentarse.

El remedio más eficaz y que nunca daña la salud es el activo ejercicio muscular. La grasa presenta la particularidad de concentrarse en las partes donde tiene mayor tranquilidad; es decir, en la nuca, en la parte superior de los brazos, en los muslos y especialmente en las caderas. ¡Cuántas señoritas, que eran esbeltas y que debido a sus obligaciones pasan todo el día sentadas en la oficina o delante de una máquina de escribir ven, con el correr de los años, aumentar la gordura de sus caderas, y más cuando no toman una medida contra este mal!" 13

Otra nota de la revista Cultura Sexualy Física sobre el resurgimiento de la educación física estaba ilustrada por dos fotos de mujeres haciendo ejercicios cuyos epígrafes versaban:

"La mujer, dada su compleja función biológica, debe interesarse por el ejercicio y la gimnasia, fuentes de vitalidad y salud, y el mejor método para conseguir y conservar la belleza del cuerpo"

"La elasticidad y el pleno dominio de sus músculos y movimientos prestan doble atractivo al cuerpo de la mujer moderna.

Estos ejercicios son muy fáciles de hacer cuando se tiene voluntad para afrontarlos" 14

Las principales partes del cuerpo objeto de cuidado de las mujeres hacia principios de siglo eran la pelvis y el abdomen (Ramaciotti y Biernat, 2011, Schagradosky, 2014). Posteriormente, cobran mayor importancia las piernas y la delgadez y las capacidades físicas prescriptas para la mujer restringidas por temor a que se dañasen sus órganos reproductivos omitían (vedaban) la velocidad, la fuerza y los ejercicios de resistencia. (Scharagrodsky, 2006) También, los movimientos y las apariencias eran objeto de generización, no sólo a través de la modelación del cuerpo sino del acto de fotografiarse.

Los indicios de que eran fotos de una joven moderna (Bontempo, 2016), además de estar indicada por las formas de mostrar el cuerpo en traje de baño, atlético y saludable, estaban cuidadosamente construidos en otras fotografías de Esther a partir de otros montajes. Por un lado, hay imágenes en/de autos cuya presencia es la referencia a la modernidad y al nivel social. La mención de Irene en la entrevista al auto de ocho asientos 
desliza una alta valoración, quizás transmitida familiarmente de aquella adquisición. La idea del viaje, del disfrute de la naturaleza en el tiempo libre y de fotografiar esos momentos también trasluce una noción de modernidad y status.

IMAGEN 14

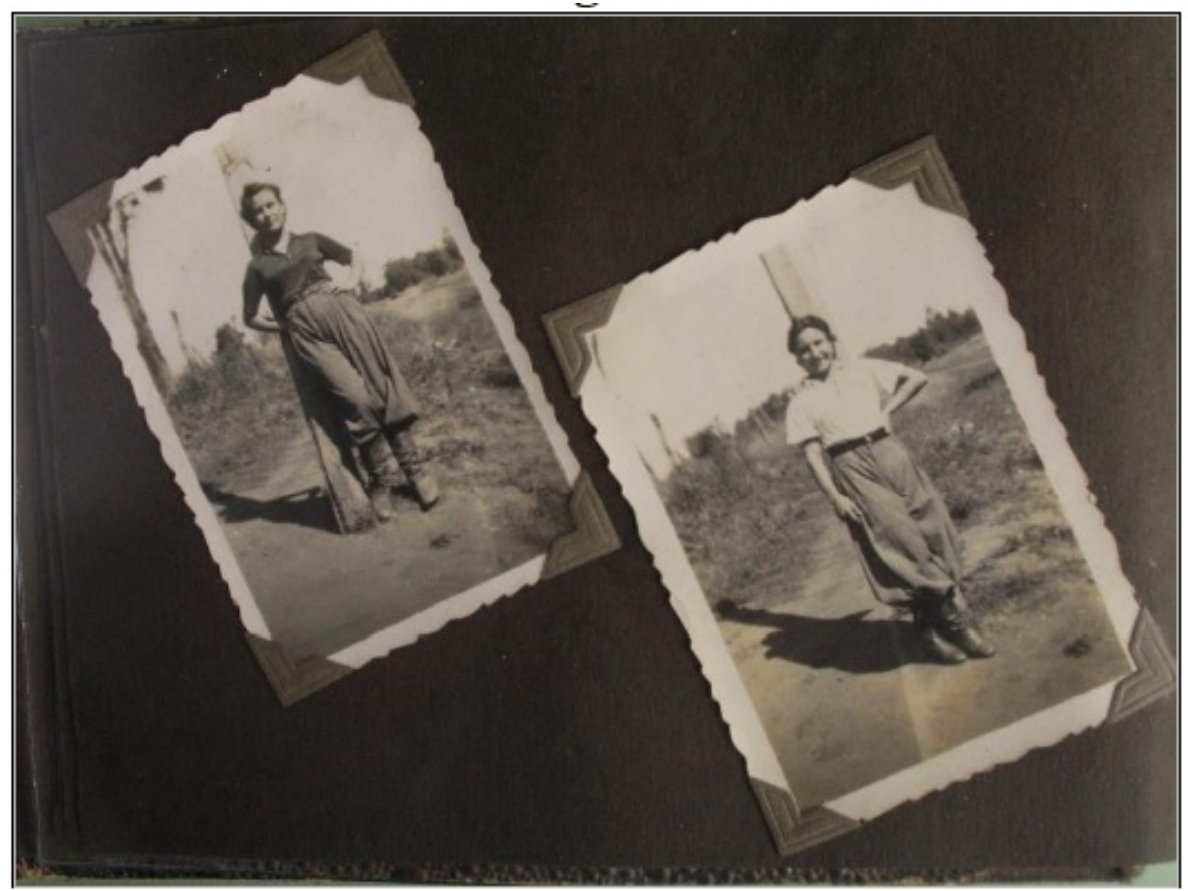

Página 6 del álbum

IMAGEN 15

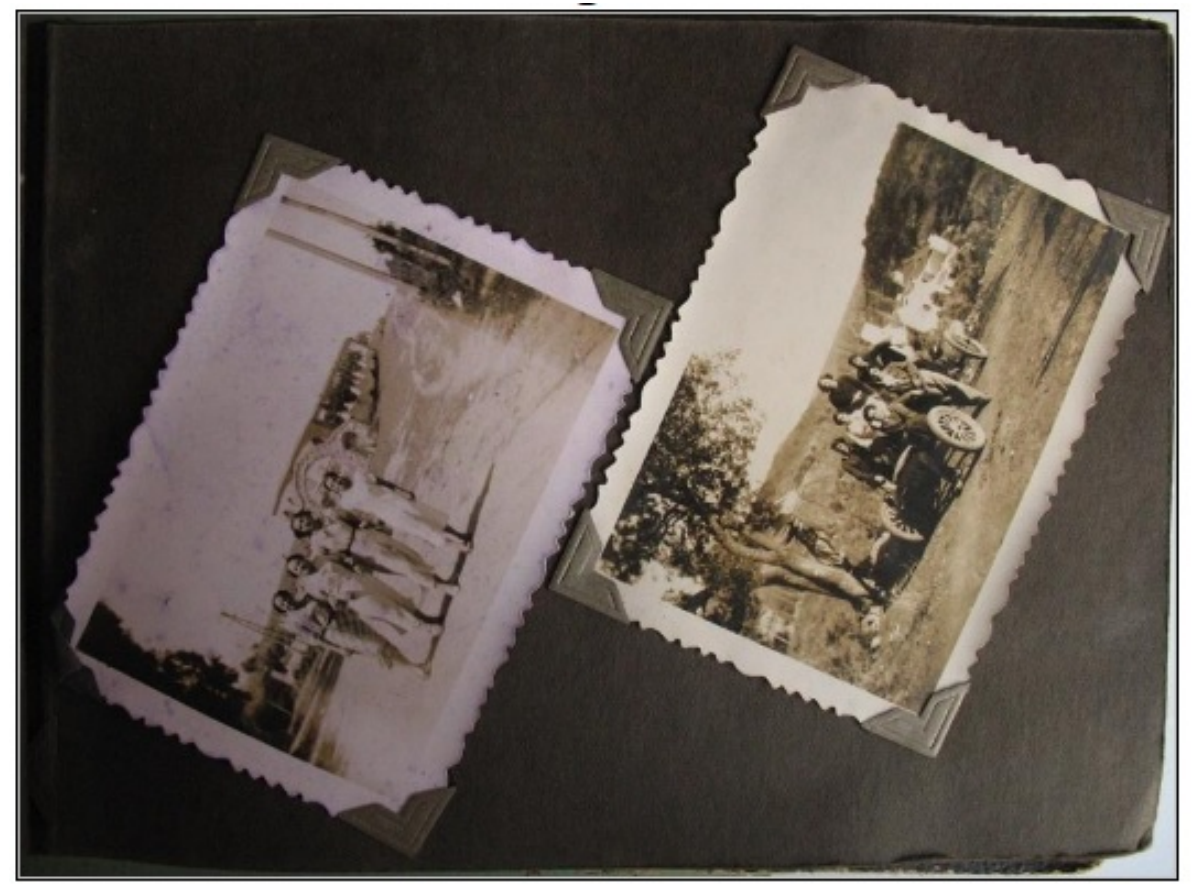

Página 17 del álbum 
Trabajos y Comunicaciones, 2da. Época, № 48, e061, julio-diciembre 2018. ISSN 2346-8971

IMAGEN 16

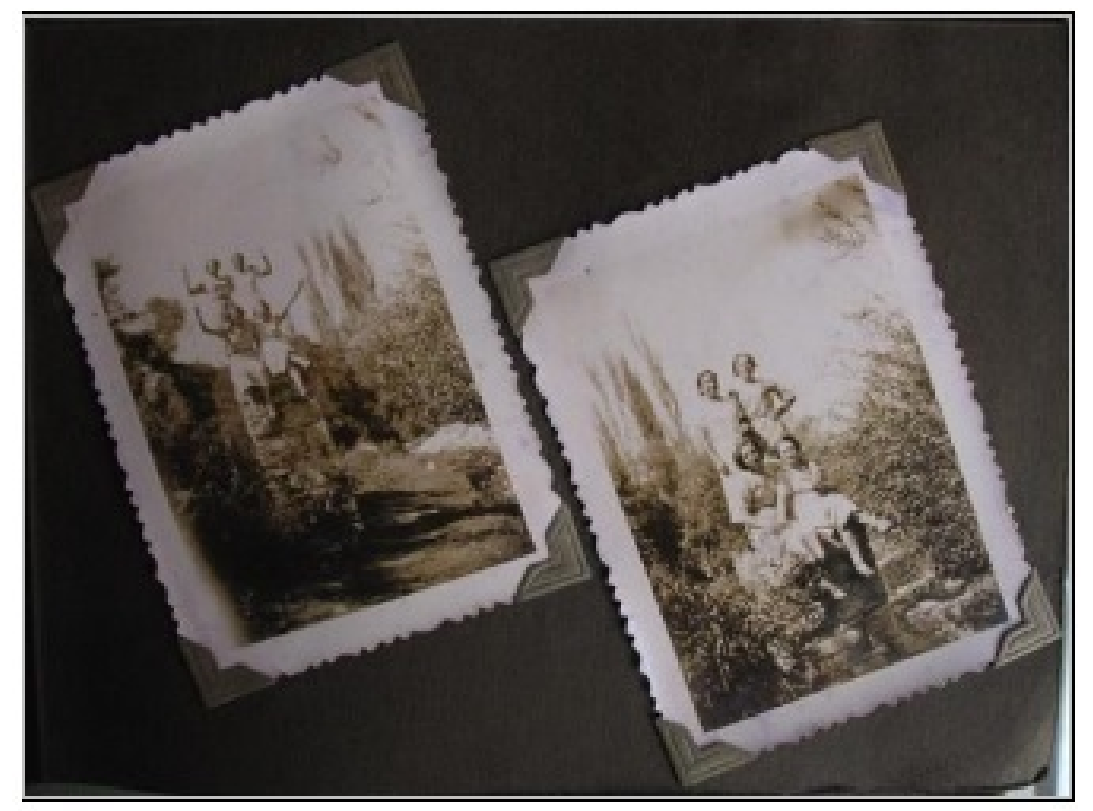

Página 19 del álbum

IMAGEN 17

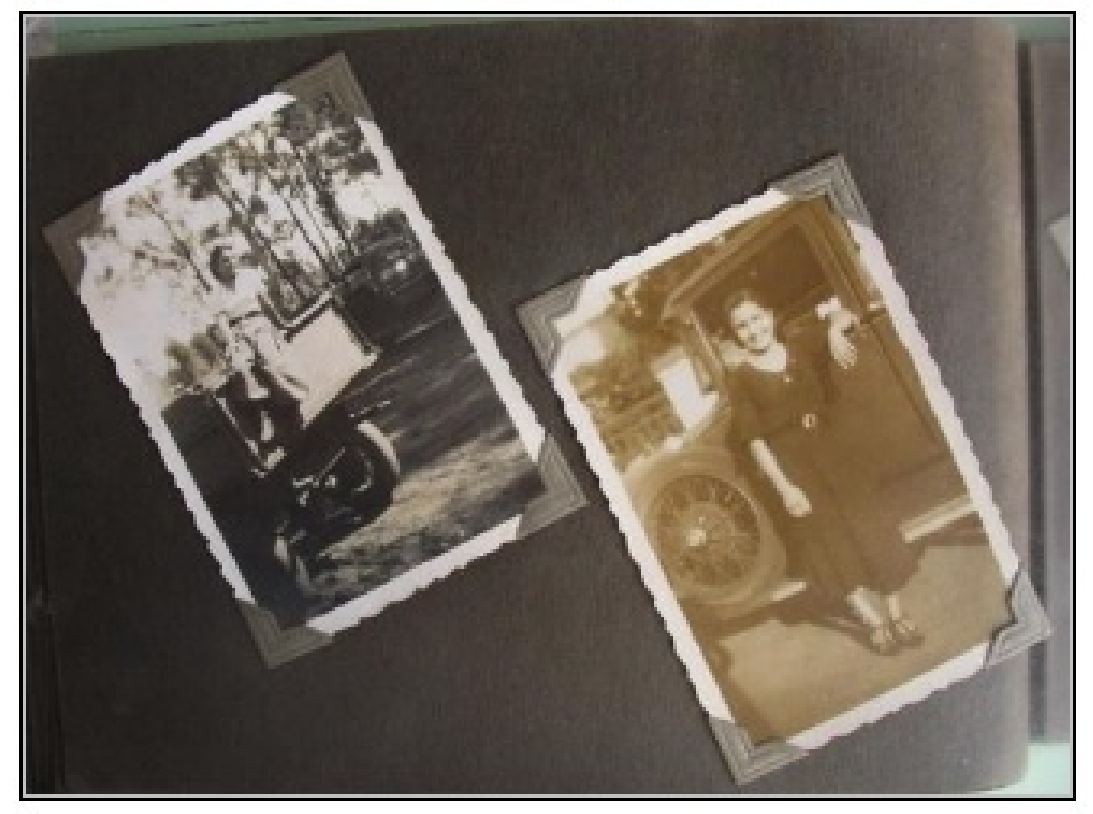

Página 22 del álbum 
IMAGEN 18

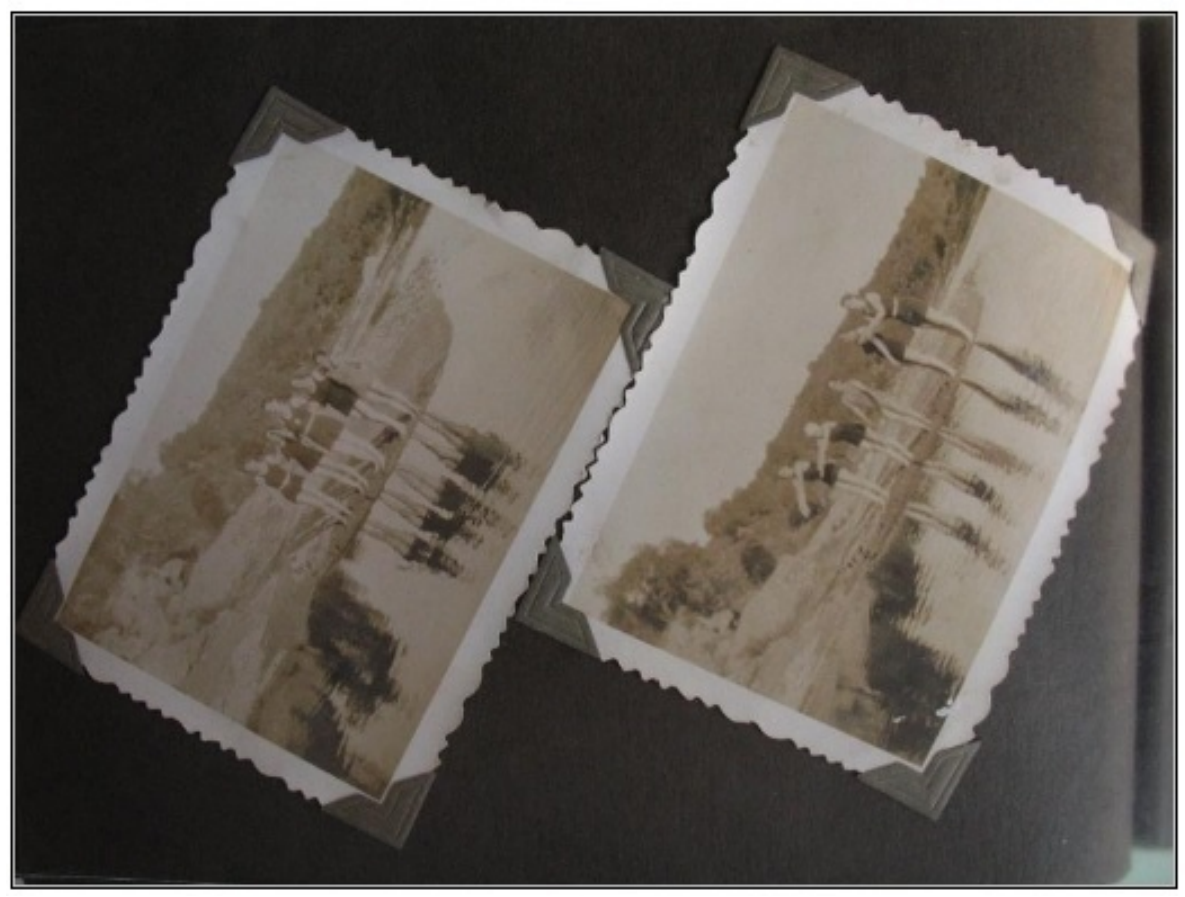

Página 24 del álbum

IMAGEN 19

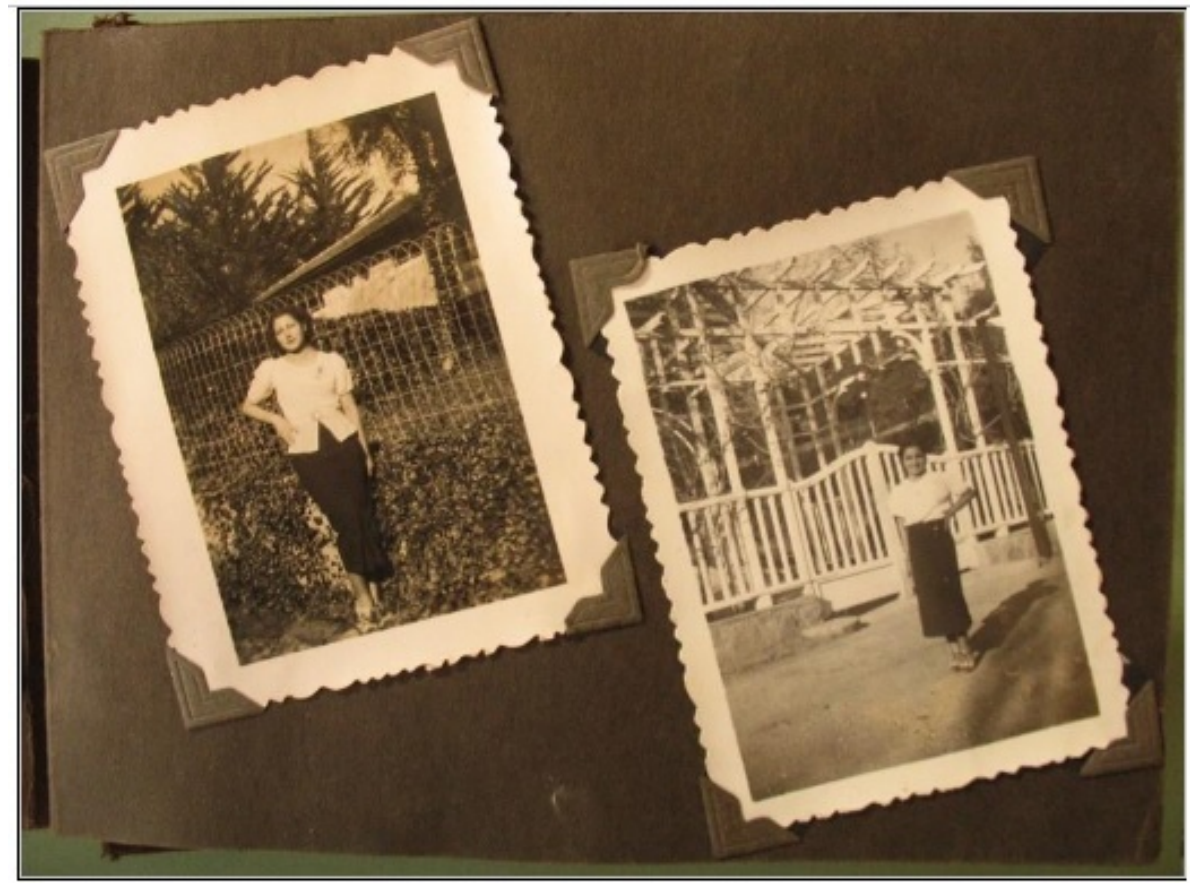

Página 43 del álbum 


\section{IMAGEN 20}

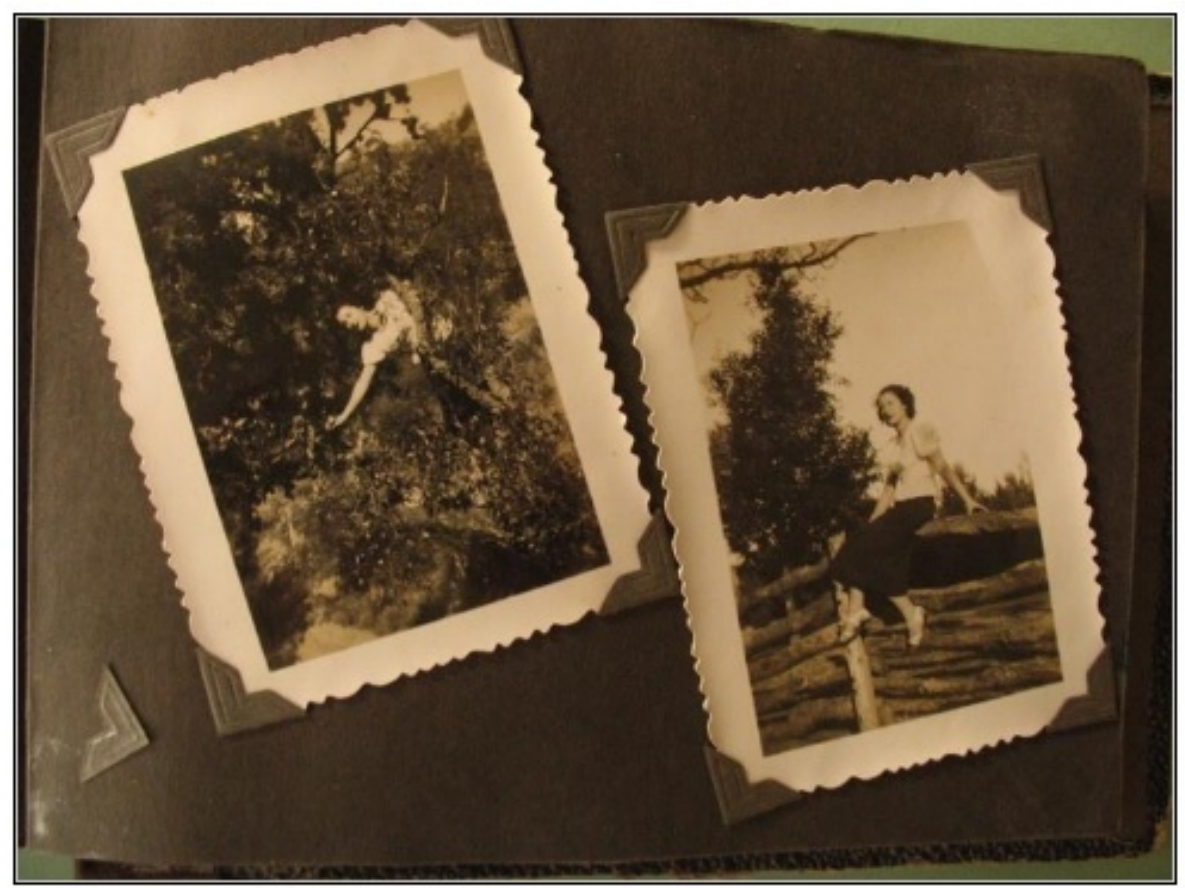

Página 45 del álbum

En las imágenes de mujeres que no se muestran en traje de baño, Esther nuevamente exacerba los rasgos seductores y lúdicos del uso de la cámara, como se puede ver en la imagen $\mathrm{n}^{\circ} 18$. Esther era aventurera y arriesgada, una mujer bella y moderna en los términos de la época: con un cuerpo delgado y musculoso, y además, fotógrafa.

El estereotipo femenino dominante de la época manifestaba y prescribía una conjunción visual del matrimonio, el amor y la sexualidad legítima-reproductora, en pos de formar una familia. Como futura ama de casa su modelo de comportamiento se realiza en función de un varón. Como han analizado varias autoras a partir de distintos registros documentales, manuales escolares, prensa escrita o políticas públicas hasta entrados los años sesenta, el destino modélico de las mujeres era el matrimonio y la maternidad (Wainerman y Heredia, 1999; Nari, 2004; Biernat y Ramacciotti, 2013; Aguilar, 2014).

No es el caso de las re-presentaciones de Esther en las que los usos de la cámara fotográfica desplazaban, de algún modo, ese modelo unívoco de "futura madre- esposa" hacia un modelo anclado en la belleza, la buena salud y la diversión. Sin dejar de considerar la posibilidad de que estos atributos fuesen atractivos para un hombre, las prácticas fotográficas de Esther retoman diversas expectativas de la época sobre el cuerpo, la salud y la belleza, que desplazan normatividades visuales hegemónicas en torno a la feminidad y la familia.

\section{A MODO DE CIERRE}

En este artículo me propuse analizar un uso de la cámara fotográfica que permite observar los modos en que retratarse a sí mismos y observar retratos de sí fue una manera de construcción de identidades de género. Una superficie que conjugaban distintos repertorios visuales y que permitían cierta navegación por parte de quienes tomaban esas imágenes y las utilizaban como objetos significativos a lo largo de sus vidas.

En este recorrido, analicé las preocupaciones en aquel período por el cuidado del cuerpo y la apariencia física. Los criterios de salud e higiene heredados de fines del siglo XIX, se articularon con las prescripciones de belleza, esbeltez, agilidad y modernidad características de la sociedad argentina del período de entreguerras. La noción de bienestar resultado de este proceso organizó las diversas políticas en torno al cuerpo, entre 
ellas también las políticas de la mirada. Si estos significados fueron el contexto en el cual los sujetos fotógrafos, fotografiados y observadores cuidaron su propio cuerpo, también fueron el horizonte de sentido de las prácticas fotográficas. El resultado fue un repertorio de imágenes que permiten ver intensificaciones, apropiaciones y en algunos casos desplazamientos en los modos de identificación como mujeres hegemónicos en la época. La captura de imágenes de distintos actos que la difusión y democratización permitió, fue consustancial a un crecimiento del grado de soberanía de los individuos (Barrancos y Ceppi, 2005: 358), soberanía que implicó un grado de autoconocimiento y autocontrol mayor y más interiorizado.

En el caso de Esther, el hecho de ser una mujer fotógrafa cobra cierta singularidad. Si bien las publicidades de la época sobre como fotografiar apelaban a la mujer como posible consumidora, la finalidad de esta práctica para el género femenino era la de retratar a sus hijos y la vida familiar. Por el contrario, Esther era una fotógrafa y una sujeta fotografiada que disfrutaba del tiempo libre, de los paseos con amigos y primos, de su cuerpo y de su agilidad. Podría argumentarse que el aire de desenfado de dichas imágenes correspondía a que eran imágenes más privadas, tomadas en contextos íntimos y reservadas de la mirada de los otros. Sin embargo, son imágenes que se enviaban a sus familiares, que se disponían en un álbum (soporte para ser mostrado) y que se mostraron a lo largo de una vida, como nos relataba la entrevistada. Además de eso debe señalarse que las imágenes debían ser reveladas en un estudio fotográfico, salvo los casos en que el grado de desarrollo personal en esa práctica permitiera revelados caseros. Desafiando algunos criterios de moralidad de la época en torno a los modos de mostrar el cuerpo femenino, pero encarnando otros como los de la salud física, los usos de la cámara de Esther representan una apropiación divertida y resultan un indicador del grado de relevancia que esas imágenes de sí tuvieron en su vida.

Desde 1930, la creciente expansión social de la capacidad de mirar a través y de verse retratados en fotografías -sin que fuese condición excluyente poseer cámara propia- transformó los modos de percibirse y de experienciar la cotidianeidad, la historia y la subjetividad. No sólo porque las prácticas fotográficsa fueron asequibles a una gran parte de la sociedad, sino también porque hubo un cambio en las nociones con las que se interpretaba ese medio. Todavía hacia comienzos de los años treinta, verse a sí mismo en fotografías constituía para muchos grupos sociales una singularidad, pero hacia fines de los años sesenta la convergencia de diversos procesos (la temprana inclusión de la fotografía en los dispositivos de control, la centralidad probatoria de los registros oculares en el campo científico, la difusión de la fotografía en la prensa, la expansión de las prácticas fotográficas) habrá posibilitado que la noción de la apariencia como expresión de la personalidad se afincara en los modos en que los sujetos se observaban e identificaban. La democratización de las prácticas fotográficas favoreció la apropiación de la imagen de sí mismos. Pero esa apropiación se generaliza hacia los años 1960, siendo en este sentido el caso de Esther muy avanzado por el tipo de uso que le da a la cámara.

Si el devenir doméstico de la fotografía estuvo en relación con los usos y significados que esa tecnología poseía en otros ámbitos -identificar a través de lo visible-, el hecho de que fuese practicada en el corazón de la privacidad, la afectividad y la realización personal -la familia- le otorgó un aire de inocencia que profundizó sus capacidades agenciales. La fotografía permitió que las imágenes de sí mismos se convirtieran en planos importantes de construcción de lo familiar y las identidades de género.

\section{REFERENCIAS}

Aguilar, P. L. (2014). El hogar como problema y como solución. Una mirada genealógica de la domesticidad a través de las politicas sociales. Argentina 1890-1940. Buenos Aires: Ediciones de CCC.

Aisenstein, A. (2006). "Cuerpo, escuela y pedagogía. Argentina, siglos XIX y XX” Pablo Scharagrodsky y Ángela Aisenstein; Tras las huellas de la Educación Física Escolar Argentina. Cuerpo, Género y Pedagogía 1880-1950. Buenos Aires: Prometeo Libros.

Annette, K. (1985). The power of the image. Essays on representation and sexuality. Nueva York: Routledge-Kegan Paul. Armus, D. (2007). La ciudad impura. Salud, tuberculosis y cultura en Buenos Aires, 1870-1950. Buenos Aires: Edhasa. 
Trabajos y Comunicaciones, 2da. Época, № 48, e061, julio-diciembre 2018. ISSN 2346-8971

Barrancos, D. (2000). Moral sexual y mujeres trabajadoras en el período de entreguerras. En: Madero, M. y Devoto, F. (dirs). Historia de la vida privada en la Argentina, T.3, Buenos Aires: Taurus.

Barrancos, D. (2007). Mujeres en la Argentina. Una Historia de cinco siglos. Buenos Aires: Sudamericana.

Barrancos, D. y Ceppi, R. (2005). Sexo-s en el lupanar: un documento fotográfico (circa 1940). Cadernos Pagu (25).

Batchen, G. (2000). Each Wild Idea.Writing Photography History. Massachusetts: MIT Press.

Biernat, C. y Ramacciotti, K. (2011). La protección a la maternidad de las trabajadoras en Argentina: aspectos legales y administrativos en la primera mitad del siglo XX. História, Ciências, Saúde - Manguinhos, Rio de Janeiro, v.18, supl.1, p.153-177.

Biernat, C. y Ramacciotti, K. (2013). Crecery multiplicarse. La politica sanitaria materno-infantilargentina 1900-1960. Buenos Aires: Biblos.

Bontempo, P. (2016). El cuerpo de la mujer moderna. la construcción de la feminidad en las revistas de la Editorial Atlántida, 1918-1933. En: Pablo Schagradosky (coordinador); Mujeres en movimiento. Deporte, cultura fisica y feminidades. Argentina, 1980-1970), Buenos Aires: Prometeo.

Bourdieu, P. (2003). Un arte medio. Ensayo sobre los usos sociales de la fotografia. Barcelona: Gustavo Gili.

Cosse, I. (2010). Pareja, sexualidad y familia en los años sesenta. Buenos Aires: Siglo XXI.

Davis, N. Z. (2013). El regreso de Martin Guerre. Madrid: Akal.

Ernst H. Gombrich, E. H. (2003). Los usos de las imágenes. Estudios sobre la función social del arte y la comunicación visual. México: Fondo de Cultura Económica.

Ginzburg, C. (1999). El queso y los gusanos. El cosmos seguín un molinero del siglo XVI. Barcelona: Atajos.

Gisela Kaczan; Representaciones de cuerpos femeninos vestidos: Códigos visuales en los mecanismos de producción de exclusión, emulación y distinción social. Mar del Plata 1900-1930. 2011. Tesis de Doctorado Interuniversitario de Historia, Facultad de Humanidades, Universidad Nacional de Mar del Plata, 2011.

Indij, G. (1992). Clic! El sonido de la muerte. Buenos Aires: La marca Editora.

Levi, G. (1990). La herencia inmaterial. la historia de un exorcista piamontés del siglo XVII. Madrid: Nerea.

Linda Martín Alcoff, L. M. (2006). Visible Identities: Race, Gender, and the Self. Nueva York: Oxford University Press.

Lobato, M.Z. (2005). Historia de las trabajadoras en la Argentina (1890-1960), Buenos Aires, Edhasa.

Moreira Leite, M (2001). Retratos de familia. Leitura da fotografía histórica. São Paulo: Editora da Universidade de São Paulo.

Mulvey, L. (2002). Visual and other pleasures. Bloomington e Indianapolis: Indiana University Press.

Nari, M. (2004). Politicas de maternidad y maternalismo politico. Buenos Aires: Biblos.

Pérez, I. (2012). El hogar tecnificado. Familias, género y vida cotidiana, 1940-1970. Buenos Aires: Biblos.

Pollock, G. (1977). What's wrong with 'Images of women'? Screen Education, № 24.

Príamo, L. (2000). "Fotografía y vida privada (1870-1930)” en Madero, M. y Devoto, F. (dirs.). Historia de la vida privada en Argentina. Buenos Aires: Taurus.

Queirolo, Graciela A. (2012). Mujeres en las oficinas. Las empleadas administrativas: entre la carrera matrimonial y la carrera laboral (Buenos Aires, 1920-1950). Diálogos - Revista do Departamento de História e do Programa de PósGraduação em História [en linea] 2012, 16 (Mayo-Agosto).

Queirolo, Graciela A.(2008). El mundo de las empleadas administrativas: Perfiles laborales y carreras individuales (Buenos Aires, 1920-1940). Trabajos y Comunicaciones., 34.

Schagradosky, P. A. (2014). Dime cómo te mueves y te diré cuál es tu "sexo": discurso médico, educación física y diferencia sexual a fines del siglo XIX y principios del siglo XX. En: Barrancos, D., Guy. D. y Valobra, A. Moralidades y comportamientos sexuales. Argentina, 1880-2011. Buenos Aires: Biblos.

Scharagrodsky, P. A. (2006). El padre de la educación física argentina: fabricando una política corporal generizada (1901-1938). En: Scharagrodsky y Ángela Aisenstein; Tras las huellas de la Educación Física Escolar Argentina. Cuerpo, Género y Pedagogia 1880-1950. Buenos Aires: Prometeo Libros.

Silva, A. (1998). Álbum de familia. La imagen de nosotros mismos. Santa Fe de Bogotá: Editorial Norma. 
Silverstone, R. (1996). Televisión y vida cotidiana. Buenos Aires: Amorrortu.

Sontag, S. (1996). Sobre la fotografia. Buenos Aires: Edhasa.

Tagg, J. (1988). The Burden of representation. Essays on photographies and histories. Minneapolis: University of Minnesota Press.

Torricella, A. (2012). Género, prácticas de re-presentación familiares-personales y fotografías. Usos y sentidos de la propia imagen y su devenir doméstico, Argentina 1930-1970. Tesis de Doctorado en Ciencias Sociales y hUmanas, UNQ. Inédita.

Torricella, A. (2018). De viajes teórico-metodológicos y mapas. Bitácora de una travesía entre la noción de representación visual como reflejo hacia la de práctica y su aplicación en una caso de estudio con fotografías familiares personales, EMPIRIA. Revista de Metodología de Ciencias Sociales, N 40 mayo-agosto, pp. 41-64.

Vazquez, P. (1986). Polaroid. O dominio do imaginario. Río de Janeiro: FUNARTE/Instituto Nacional da Fotografía.

Vigarello, G. (2005). Historia de la belleza. El cuerpo y el arte de embellecer desde el Renacimiento hasta nuestros dias. Buenos Aires: Nueva Visión.

Vigarello, G. (2006). Entrenarse. En Corbin, A., Courtine, J. J. y Vigarello, G. (dirs.). Historia del Cuerpo III. Las mutaciones de la mirada. El siglo XX. Madrid: Taurus.

Wainerman, C. y Heredia, M. (1999). ¿Mamá amasa la masa? Cien años en los libros de lectura de la escuela primaria. Buenos Aires: Editorial de Belgrano.

\section{Notas}

1 Me refiero en particular a la los primeros estudios culturales feministas, pero en general es una hipótesis de todos los trabajos que relacionan fotografía con control y relaciones de poder en el campo de la visión. Ver los clásicos de Griselda Pollock (1977), Annette Khun (1985) y Laura Mulvey (2002). También puede consultarse el ensayo de Susan Sontag (1996) y el trabajo de John Tagg (1993).

2 Entrevista realizada por la autora en Mar del Plata el 25 de Septiembre de 2009 a Irene Logarzo. En adelante nos referiremos solo a esta entrevista.

3 Entrevista a Irene 25/09/09.

4 Ver los clásicos trabajos de microhistoria de G. Levi (1990), N. Z. Davis (2013) y C. Ginzburg (1996), sobre la importancia de los estudios de casos singulares para pensar problemas más amplios.

5 Las identidades sociales de género operan a través de marcas corporales (Alcoff, 2006).

6 Ernst H. Gombrich denominó la "domesticación de la pintura de caballete" la reproducción de obras de arte en interiores "filisteos con una función recordatoria de las grandes obras de arte (Gombrich, 2003). "Domesticación” también es un concepto utilizado por Roger Silverstone (1996).

7 Sin embargo, este devenir doméstico de la propia imagen no significó un proceso lineal de incorporación de la cámara como objeto de consumo en todos los hogares. Si bien esta tendencia fue en aumento a medida que se perfeccionaba la técnica y se abarataban los costos de los aparatos, los usos familiares y personales de la propia imagen consistían en una heterogeneidad de prácticas que convergían en el espacio de lo doméstico y familiar: la foto comercial de estudio, la fotografía callejera, las anónimas fotos tomadas por manos trabajadoras, la foto de identidad y las fotos que las propias familias se sacaban con sus cámaras (Batchen, 2000).

8 "Si bien el significado del casamiento difería según el género, determinaba el carácter normal o anómalo de la trayectoria personal para mujeres y varones. Este rasgo resulta especialmente claro al observar las representaciones de quienes no lograban llegar o mantener su matrimonio (...) Socialmente la soltería definía a quienes no habían podido concretar las expectativas propias y familiares depositadas en el casamiento"(Cosse, 2010: 119-120).

9 "Es éste su problema”, Vosotras, 10 de marzo de 1950. Citado en Isabella Cosse (2010: 121).

10 Un análisis detallado de este cambio lo realiza Gisela Kaczan en su Tesis de Doctorado (2011).

11 "El baño es un signo de liberación moderna", Cultura sexual y física, Buenos Aires, № 16, Noviembre de 1938.

12 Pedro Vasquez sostiene que la Polaroid posibilitó por su instantaneidad un uso erótico doméstico: "Si el público adhirió en masa al polaroid, no fue movido por la voluntad de interpretar visualmente la belleza circundante, sino por la atracción proporcionada por su carácter intimista, una vez que se dispensó de la intermediación de los laboratorios profesionales para acceder al resultado final -lo que posibilitó el florecimiento de la pornografía familiar"(Vazquez: 1986). Traducido y publicado por Guido Indij (1992: 120).

13 "El deseo de ser esbelta", El Gráfico, 1 de diciembre de 1937. 
Trabajos y Comunicaciones, 2da. Época, № 48, e061, julio-diciembre 2018. ISSN 2346-8971

14 Cultura sexual y fisica, Buenos Aires, № 21, Abril de 1939. Ver también "Cómo puede la mujer lograr el porte perfecto 